\title{
Epistemic Investigation into the Problems and Challenges of Philosophy in Nigerian Society
}

\author{
Olisa Raphael Maduabuchi, Eugene Anowai \\ Department of Philosophy, Chukwuemeka Odumegwu Ojukwu University, Igbariam Campus, Anambra, Nigeria \\ Email: maduabuchiolisa@yahoo.com
}

How to cite this paper: Maduabuchi, O. R., \& Anowai, E. (2018). Epistemic Investigation into the Problems and Challenges of Philosophy in Nigerian Society. Open Journal of Philosophy, 8, 428-435. https://doi.org/10.4236/ojpp.2018.84029

Received: June 7, 2018

Accepted: August 26, 2018

Published: August 29, 2018

Copyright $\odot 2018$ by authors and Scientific Research Publishing Inc. This work is licensed under the Creative Commons Attribution International License (CC BY 4.0).

http://creativecommons.org/licenses/by/4.0/

\begin{abstract}
This paper sought to examine the problems and challenges of Philosophy in Nigeria. Philosophy is an abstract discipline whose relevance is grossly contested in the world. In Nigeria, philosophy is misconceived as a fruitless academic venture without any practical utility. Nigerian philosophers are facing many problems and challenges in this $21^{\text {st }}$ century. The work recommended that Nigerian philosophers should stand up to their responsibility and confront the challenges bedeviling their disciplines in order to solve the problems of Nigerian society.
\end{abstract}

\section{Keywords}

Philosophy, Problems, Challenges, Discipline, Academic and Nigeria

\section{Introduction}

Philosophy is the foundational discipline in academic world. Every academic discipline originated from Philosophy. Philosophy touches every aspect of human endeavour. No wonder UNESCO recognizes the third Thursday of November every year as World Philosophy Day. But, Olaopa (2014) conceived that many people all over the world do not take cognizance of it because philosophy is misconceived as an invisible abstract discipline whose relevance is grossly contested.

This negative ideology people have about philosophy influences people's attitude towards philosophy especially in the developing countries like Nigeria. During my postgraduate studies at University of Nigeria Nsukka, a priest was giving a sermon to students in the morning mass and when he was advising them to study good course that will put food in their table. He asked, "After studying some courses like Philosophy, what can you do with it?" Many students 
were making mockery of philosophy students after the mass.

Nigerians do not value Philosophy. Maduabuchi and Anowai (2016) pointed out that some students who are studying Philosophy in the universities see themselves as victims of circumstance who could not gain admission into their choice courses. In the same line of thought, many seminarians are studying Philosophy because seminary formation requires that seminarians must study Philosophy before they do Theology or become a priest. When some seminarians come out of seminary, they become confused on the course they would study in the university if they want to continue with their education.

The theme of this year's NAPS symposium: "Philosophy in the $21^{\text {st }}$ Century Nigeria: Problems and Prospects" is important to address this negative attitude of people towards Philosophy. Philosophy is very vital for the development of human thought, for people's culture and individual growth. Thus, this paper tends to look into the problems and challenges of Philosophy in Nigerian society.

The key concepts that are associated with this study are: philosophy, problems and challenges. There is no universal or succinct definition of philosophy. Etymologically, philosophy is derived from two Greek words " $\varphi \iota \lambda \iota \alpha$ " (philia)-love

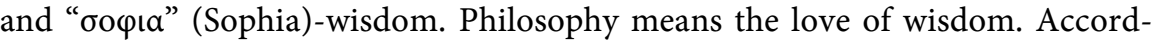
ing to Wikipedia Contributors (2018), philosophy is the study of general and fundamental problems concerning matters such as existence, knowledge, values, reason, mind, and language. In fact, philosophy studies reality, values and knowledge as a whole.

The term "philosophy" as used by the ancient Greek scholars meant the pursuit of knowledge for its own sake, and comprised all areas of speculative thought, including the arts, sciences and religion (Mastin, 2009). In the book A(1) of Metaphysics, Aristotle conceived that science which does not aim at utility originated in Egypt when the priestly caste were allowed to be in recreation (Mikeon, 2001). Thus, philosophy is a science which does not aim at utility. Philosophical questions unlike those of sciences are usually foundational and abstract in nature. Philosophy is done primarily through reflection and does not tend to rely on experiment, although the methods used to study it may be analogous to those used in the study of the natural sciences (Mastin, 2009: p. 1).

Another concept that is associated with this study is problem. According to Cambridge Advanced Learner's Dictionary and Thesaurus (2018), problem is a situation, person, or thing that needs attention and needs to be dealt with or solved. Problem can be conceived in many ways, it can be a missing gap, unsatisfactory state of affairs or a deviation from a norm, standard, or status quo. In most cases, problems are associated with challenges. On the other hand, a challenge is something needing great mental or physical effort in order to be done successfully or the situation of facing this kind of effort (Cambridge English Dictionary, 2018). Philosophy is problematic in nature which requires frantic effort in order to be tackled. Thus, the problems and challenges of philosophy will be addressed in this paper. 


\section{Theoretical Framework}

This work is anchored basically on cognitive theory of learning. According to Ngwoke (2010), "the cognitive field theory deals with the problem of how an individual gains an understanding of himself, and his environment, how he uses his knowledge, experience and motivational status to act in relation to his environment". This is in line with educational philosophy which recommends that education takes into consideration the needs and aspiration of the society. Hence, Maduabuchi (2017) envisaged that any educational curriculum or system which does not address the needs and aspirations of the society is dysfunctional. However, cognitive theory emphasizes change in perception, knowledge or purpose. The scholars that promoted this theory in the field of education include: Jerome Bruno, Jean Piaget and so on.

Jerome Bruno conceived thinking as the outcome of cognitive development. Cognitive development is the aspect of learning that deals with development of knowledge. In his view, experience plays an important role in the education of the child because the intelligent mind creates the generic coding systems from experience, which enable one to go beyond the data to new predictions or knowledge (Bruno, 1957). So, the important outcome of learning for him to make new discovery. In this regard, education is geared to create autonomous individuals or learners. He went further to propose three modes of representations in which knowledge or information is stored in human memory. The first stage is enactive representation which deals with encoding action based information. The second stage is iconic representation where action is stored virtually inform of images and the final sage is symbolic representation. Here, information is stored inform of a code or symbol such as language (Mcleod, 2012). Language is one of the principle foundations of human knowledge, which enhances the ability to deal with abstract concept. Thus, education is geared to facilitate human thinking and problem solving skills, which can be transferred to wide range of situations.

Moreso, Jean Piaget's theory of cognitive development deals with intellectual development of children, which has a tremendous impact on developmental psychology. Piaget cognitive theory is geared towards constructing internal structures and functions. Contrary to traditional education which conceives the child as a miniature adult, Piaget envisages that children have a peculiar way of thinking which is quite different from adult. Ngwoke and Eze, (2010) buttressed that the way a child perceives the world depends on how he acts on things around him. The way the child acts on his environment constitutes his cognitive structure which changes as he experience new things in the environment while cognitive functions are the inherited and innate biological mechanism that guides development. The cognitive functions of the child are central to Piaget's theory of cognitive development. In his view, there are two generation functions in man. The first one is organization. Organization has to do with the tendency for all species to order knowledge into a coherent system of interrelationships. 
On the other hand, adaptation is the tendency for all species to adapt to their environment in order to survive (Ngwoke \& Eze, 2010: p. 23) He further buttresses that adaptation is classified into two subdivisions such as: assimilation and accommodation. Assimilation is the inclination for an organism to interpret new experience in terms of its current structures. But, accommodation is the restructuring of cognitive structure to suit a new experience. Thus, assimilation and accommodation work together.

Another important aspect of Piaget's theory of cognitive development is constructivism. Cherry (2018) postulated that constructivism is the theory which postulates that people actively construct their knowledge of the world based on the interactions between their ideas and their experiences. Learners construct knowledge of their environment instead of accumulating sensation from their environment. Piaget conceived that the modalities of assimilation, accommodation, and construction of novel knowledge are a life-long process. Having underlined the theoretical framework of this work, it is inherent to address the problem and challenges of Philosophy.

\section{The Problems and Challenges Facing Philosophers in Nigeria}

Problems are associated with challenges. Every problem requires some challenges in order to tackle it. For instance, the problems of Philosophy in Nigeria constitute a challenge which Nigerian philosophers ought to address and proffer solutions to them.

In the first instance, philosophy is problematic in nature. Philosophy can be understood from different perspectives. In a way, philosophy is conceived as an ideology. According to Hornby (2011), an ideology is a set of ideas, wisdom or beliefs, especially one held by a particular group or individual, which influences the way people behave. Nigerians are lacking good philosophical ideology in many spheres of life. For instance, in the area of politics some leaders in developing nations like Africa take advantage of the citizens by misappropriating and embezzling the available resources and converting them to personal gain. Plato conceived that the state will be good when philosophers become kings and kings become philosopher. Philosophers are educated to pilot the affairs of the state. In some countries like United Kingdom, philosophers, economists and political scientists occupy their position and execute their roles in politics. But, philosophers are denied of their central role in the Nigerian politics and other areas in the socio-political life of Nigeria. Many things have gone wrong in Nigeria because philosophers are neglected.

Hence, Nigeria educational system is in shamble because our leaders are not fully educated. Education is not properly funded. There is more or less no functional philosophy of education in Nigeria. It is unfortunate that Nigerians are still using the old philosophy of education, which was promulgated in the curriculum conference of 1969 in this present $21^{\text {st }}$ century world. According to Na- 
tional Policy on Education (2004) of the Federal Republic of Nigeria, Nigeria's philosophy of education therefore is based on:

1) The development of the individual into a sound and effective citizens 2) The full integration of the individual into the community; and 3) The provision of equal access to educational opportunities for all citizens of the country at the primary, secondary and tertiary level both inside and the outside the formal school system (p.7)

Philosophers play effective role in the curriculum planning and implementation. Ayozie (2002) conceived that curriculum planners make use of the services of philosophers to ensure that the goals of education synchronize with the needs and aspirations of the society. But, Nigeria's philosophy of education is formulated without involving philosophers. No wonder, Nigeria educational system is not functioning properly because philosophers are not allowed to take their rightful position in education. According to Okafor (1992), philosophy provides the need for a careful examination and validation of principles in the educative process to determine whether or not they accord with other true nature of the individual, with life, and the life ultimate potentials or purpose.

However, the academic enterprise of philosophy is not valued in Nigeria. The American Council of Learned Societies (2014) had lamented that philosophy and other humanistic studies have been deprioritized by policymakers and even by some university officials in today's landscape of higher education and research in Africa. But, philosophy is the core humanistic discipline that constitutes the interior mission of a university and national goal.

Philosophy is, thereby, misconceived as a fruitless academic venture which has no practical relevance in life. Unlike engineering and sciences, students' enrolment in philosophy is poor in the universities and other institutions of higher learning. Besides, there are other problems of philosophy within. Philosophy is a difficult subject because its course of study is abstract. In the Colleges of education, faculties of education in the universities and schools of education in the Polytechnics, philosophy is dreaded as a "no-go-area".

Philosophy constitutes a problem to itself. The problematic nature of the discipline has made it that philosophers have no general agreement on any issue. There are many philosophical problems in the history of philosophy which are still recurrent even in this present age such as: appearance and reality, change and permanence, one and many etc. Philosophers have no final or definite answer to any philosophical questions or problems. Thus, philosophical questions geared to sharpen the focus of philosophy, which do not require any definite answer.

\section{The Prospects of Philosophy}

Philosophy is a conglomeration of all disciplines because philosophy studies the whole reality. In the ancient time, philosophy included many disciplines like medicine, natural sciences, psychology, mathematics, economics, sociology, lin- 
guistics and so on. In fact, all academic disciplines originated from philosophy. Today all academic disciplines are still under the guidance of philosophy. There is philosophy of every discipline in the academic world. As such, the services of philosophers are needed in every field of human endeavour.

Philosophers are found in wide range of careers ranging from politics, education, public sectors like civil service, health services, police forces, armed forces, governmental policy work and other areas. There are many administrative and other office-based roles found across all these areas where philosophers perform important duties (Tucker, 2015).

Graduates of philosophy acquire the skills of problem-solving and critical thinking which make them creative in many areas like business. A well grounded wisdom of philosophical mind can make one to be successful in business.

Philosophy equips people with reading and writing skills. These skills can find useful application for career like publishing. Thus, the services of philosophers can be relevant in the production of magazines, books, newspapers and academic journals and other forms of publishable media. It can also include roles in editorial, production, marketing and sales.

Philosophers are endowed with good communication and public speaking skill, which can be implemented in journalism. The roles philosophers can perform in journalism can focus on research, writing, editing, presenting and various forms of broadcasting and multimedia.

The ability to think and write clearly, to analyze and present arguments, is highly valued in the law profession. A degree in Philosophy can provide a good foundation for law school. Besides, some of the courses in philosophy are related to law like philosophical jurisprudence, ethics and political philosophy.

In fact, philosophers are found in every career as a result of the broad nature of the discipline. In the medical profession, philosophers are found as practitioners and administrators. Medical schools look favorably upon candidates with a liberal arts degree, especially from philosophy departments (Maryland: Department of Philosophy, n.d). Hence, philosophers are endowed with good leadership skill, which is important in hospital or health administration. Other areas where the services of philosophers are needed include: foreign service, clergy, teaching, non-governmental organization and so on. Philosophers are active as entrepreneurs in the cultural sector, working with clients to provide a variety of services in the area of philosophical consulting and ongoing education beyond the walls of the academic (Van Dijk, n.d). Thus, philosophical training gives philosophers an edge in establishing themselves and advancing in their various workplaces.

\section{Evaluation}

This study examines the problems and challenges of Philosophy in Nigerian society. The work makes use of expository and analytic methods in order to expose and analyse the challenges confronting Nigerian philosophers. Nigeria socio-political life is bedeviled with many problems ranging from political instabil- 
ity, national disunity, tribalism, religious violence, insecurity and so on. In Western world, people look up to philosophers to resolve the problems of society but the story is different in Nigeria. Philosophy is utilized mainly by the Church in training their future ministers. There is the need for Nigerian philosophers to rise up and take up their responsibility in the socio-political life of Nigeria. Achebe (1980) observed rightly that the trouble with Nigeria is in their leaders. Nigerians have to change their mindset about politics. Politics is not reserved only for the bad and past corrupt leaders of Nigeria. Philosophers in Nigeria ought to enter political party and take active role in Nigeria politics because good leadership is a conditio-sine qua non for economic growth and national development.

Education is a veritable instrument for national development. As such, philosophy and goals of education in Nigeria should be reviewed by philosophers to reflect the needs and aspirations of Nigeria society in this $21^{\text {st }}$ century. Philosophy is the foundation of education. Nigerian philosophers should take active role in education both in the administration and teaching. A true philosopher is one whose search is for wisdom, accuracy, truth and right. When philosophers are fully engaged in education, it will go a long to tackle the problems of education in Nigeria.

However, professional philosophers in Nigeria should come together and promote philosophy in Nigeria. It is not enough for them to converge together biannually or annually for a philosophy conference. They must ensure that academic excellence and merit reign in philosophy department of their various institutions. Their greatest task lies in training and imparting the knowledge of philosophy to the young philosophy students. They should encourage and break down the subject matter content in manner that it will be comprehensible to students. It will encourage the students to develop their potential and burst their morale to venture and develop the different areas of philosophy in their postgraduate studies.

Finally, philosophy students in Nigeria should work hand in hand with their senior colleagues. The annual national convention of philosophy students is a laudable programme, which is geared for philosophy students of Nigeria to know themselves. It also serves to mentor and promote the knowledge of philosophy among our young philosophy students.

\section{Conclusion}

This work has x-rayed the problems of philosophy in Nigeria. The problems and challenges confronting philosophers in Nigeria require frantic effort on the part of Nigeria philosophers in order to tackle the situation. Philosophy enables people to develop critical mind, problem-solving and other skills that will enable them to solve people's problem and tackle the challenges of life in Nigeria.

\section{Conflicts of Interest}

The authors declare no conflicts of interest regarding the publication of this paper. 


\section{References}

Achebe, C. (1980). The Trouble with Nigeria (p. 1). Enugu Fourth Dimension Publishing Co. Ltd.

American Council of Learned Society (2014). Recommendation for Reinvigorating the Humanities in Africa.

https://www.acls.org/uploadedFiles/.../Reinvigorating_the_Humanities_in_Africa.pdf

Ayozie, B. (2002). Situational Analysis in Curriculum Development and Planning. In: G. C. Offorma (Ed.), Curriculum Theory and Planning (p. 72). Enugu: Family Circle Publication.

Bruno, J. S (1957). Going Beyond Information Given (p. 234). New York: Norton.

Cambridge Advanced Learner's Dictionary and Thesaurus (2018). Meaning of "Problem". https://dictionary.cambridge.org/dictionary/english/problem

Cambridge English Dictionary (2018). Definition of "Challenge". https://dictionary.cambridge.org/us/dictionary/english/challenge

Department of Philosophy (n.d.). Careers for Philosophy Majors. http://www.philosophy.umd.edu/undergraduate/careers

Federal Republic of Nigeria (2004). National Policy on Education (4th ed., p. 7). Yaba: NERDC Press.

Hornby, A. S. (2011). Oxford Advanced Learner's Dictionary, International Students Edition (p. 744). New York: Oxford University Press.

Maduabuchi, O. (2017). Philosophical Issues in Education (p. 16). Onitsha: Bookpoint Ltd.

Maduabuchi, O. R., \& Anowai, E. C. (2016). Philosophy as Self Formation: Geared Towards National Transformation and Progress. Journal of Assertiveness, 10, 13-20.

Mastin, L. (2009). What Is Philosophy? The Basis of Philosophy.

http://www.philosophybasics.com/general_whatis.html

Mcleod, S. (2012). Bruno. http://www.simplypsychology.org/Bruno.htm

Mikeon, R. (Ed.) (2001) Metaphysics in the Basic Works of Aristotle (pp. 689-691). New York: Modern Library Publishers.

Ngwoke, D. U. (2010). School Learning: Theory and Application (2nd ed., p. 57). Enugu: Immaculate.

Ngwoke, D. U., \& Eze, U. N. (2010). Developmental Psychology (pp. 21-22). Enugu: Timex Enterprise.

Okafor, F. C. (1992). Philosophy of Education and Third World Perspective (4th ed., p. 21). Enugu: Brunswick Publishing Co.

Olaopa, T. (2014). Philosophy and the National Question in Nigeria. http://thenationonlineng.net/philosophy-and-the-national-question-in-nigeria/

Tucker (2015). What Can You Do with a Philosophy Degree. https://www.topuniversities.com/student-info/careers-advice/what-can-you-do-philoso phy-degree

Van Dijk, A. N. (n.d.). Career Prosects. https://www.uu.nl/masters/en/philosophy/career-prospects

Wikipedia Contributor (2018). Philosophy from Wikipedia, the Free Encyclopedia. https://en.wikipedia.org/wiki/Philosophy 